\title{
"SERTOLI" AND "LEYDIG" CELLS IN RELATION TO OVARIAN TUMOURS
}

\author{
BY \\ F. A. LANGLEY \\ From the Departments of Obstetrics and Gynaecology and of Pathology, University of Manchester
}

(RECEIVED FOR PUBLICATION JULY 22, 1953)

The group of tumours termed arrhenoblastomas was separated from the general body of ovarian tumours by Meyer $(1915,1930,1931)$. Barzilai (1949) defines the arrhenoblastoma, in conformity with Meyer's views, as "an ovarian tumour the cytoarchitecture of which almost exacly duplicates that seen in the different stages of male gonadogenesis." Thus, although many of these tumours have a masculinizing or defeminizing effect on the host this is not essential for the diagnosis. Descriptions of about 122 of these tumours have been published (Javert and Finn, 1951). Three types of tumour pattern are recognized: (1) a highly differentiated pattern composed of well-developed tubules lined by cubical or columnar cells with basal nuclei, closely resembling Sertoli cells and the late developmental stages of gonadogenesis, as seen in the undescended testis ; $(2)$ one in which the tumour looks like a fibromatous or sarcomatous neoplasm ; and (3) a pattern intermediate between these two extremes. Barzilai (1949) and Novak (1952) have drawn attention to the large polyhedral eosinophilic cells which frequently lie in the stroma of the tumours and resemble Leydig cells. The work of Sternberg (1949) and of Teilum (1949) allows the separation from this heterogeneous group of two distinct entities $(a)$ "Leydig" cell tumours and (b) "Sertoli" cell tumours; a third form of tumour also exists in which both "Sertoli" cells and " Leydig " cells occur.

In this paper it is proposed to describe and discuss two tumours, which are morphologically arrhenoblastomas, in the light of these newer concepts, and also a case of bilateral Leydig cell tumour, or hyperplasia, with masculinization.

\section{Case Reports}

Case 1.-E. J., a married woman of 64, had menstruated irregularly from the age of 17 until her menopause at 50 years. There had been no pregnancies. For the last 14 years there had been facial hirsuties, increasing recently, and on admission she had a beard on the chin and lips. The pubic and axillary hair were feminine. Her voice had become masculine in the last 12 years. Her breasts were normal apart from a rubbery swelling $\frac{1}{2}$ in. in diameter in one of them. She was obese. Her blood pressure was $200 / 130 \mathrm{~mm}$. Hg. The vulva and vagina were atrophic. A radiograph of the sella turcica suggested no significant abnormality. On rectal examination a pelvic tumour was felt on the left side. The excretion of ketosteroids was $6.9 \mathrm{mg}$. $/ 24 \mathrm{hrs}$. (normal 8-17 mg./24 hrs.), and more than 19 mouse units of gonadotrophin were excreted in 24 hours (normal 12-25 mouse units $/ 24 \mathrm{hrs}$., see Table I). The uterus and adnexae were removed. The patient was seen again 15 months later. There was no significant change clinically, the facial hirsuties persisting and obesity increasing, and the daily excretion of ketosteroids and gonadotrophins remained substantially the same as before the operation.

Macroscopic Appearances.-The uterus was lobular and enlarged by a number of fibroids. The ovaries were slightly enlarged, corresponding in size to those found in the child-bearing period; they contained small cysts and corpora albicantia.

Microscopic Appearances.-The ovaries are slightly enlarged and contain corpora albicantia and germinal inclusion cysts. The ovarian stroma is well developed and composed of intertwining bundles of connective tissue. In the interstices of the stroma are groups of cells with eosinophilic cytoplasm (Fig. 1). These are usually polygonal but in places the corners of the cells are rounded and in others drawn out giving a rather stellate appearance to the cells. The nuclei are round, each having a dense nuclear membrane, a well-defined but light chromatin pattern, and usually a nucleolus. These groups of cells are essentially similar to other groups present in unusually large numbers at the hilum of the ovary in close apposition to non-myelinated nerves and blood vessels, with the possible exception that the nuclei of the hilar cells are denser (Fig. 2).

The cytoplasm of the cells of both groups presents certain features: (1) Some cells possess brown pigment granules (Fig. 3). (2) Some of the cells at the hilum contain small bodies resembling Reinke crystalloids (Fig. 4) as seen in the interstitial cells of 
TABLE I

DAILY URINARY EXCRETION OF HORMONES

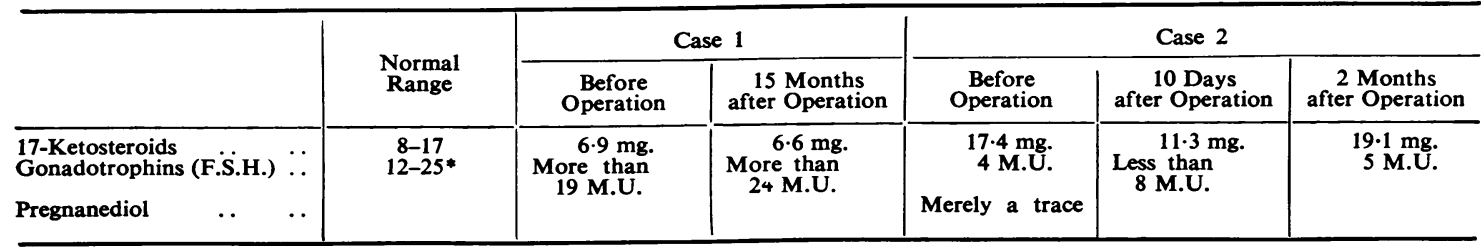

* The normal range in the child-bearing period, except just before ovulation.

the testis. (3) Many cells of both groups give a positive reaction with Vines stain more common in the groups at the hilum than in those at the substance of the ovary. The positively reacting material is granular. (4) Some cells of both groups give a positive P.A.S. reaction. This does not occur so frequently as the positive Vines reaction and may be related to the presence of the brown pigment. (5) The cytoplasm of both groups of cells stains faintly with Sudan IV and some have, in addition, granules which stain more deeply. In the stroma there are occasional clusters of sudanophilic granules, but it is difficult to be sure whether these are in the stromal cells or in isolated eosinophilic cells. (6) The cytoplasmic granules stain deeply with phosphotungstic acid haematoxylin.

The relationship of the groups of cells within the ovary to the ovarian stroma is very intimate, collagen fibres (as shown by Van Gieson's stain, Heidenhain's azan, and silver impregnation) penetrating between the individual cells. The impression is given that these eosinophilic cells are derived from the stromal cells, but the evidence is not conclusive and it may be that the stroma is reacting to the presence of these cells as it does in secondary carcinoma of the Krukenberg type.

Case 2.-C. T., an unmarried girl of 18 years, had had four menstrual periods since her menarche at 16 . There was facial hirsuties necessitating frequent shaving, a small amount of hair round the nipples, and marked hypertrichosis of legs and back. Pubic hair was of masculine distribution. The clitoris was enlarged. The body outline was masculine, but the voice feminine. The blood pressure was $135 / 70 \mathrm{~mm}$. $\mathrm{Hg}$; 17-ketosteroid excretion was $17.4 \mathrm{mg} . / 24 \mathrm{hrs}$. (normal 8-17 mg./24 hrs.), 4 mouse units of gonadotrophin were excreted per day and only a trace of pregnanediol. On vaginal examinạtion a cystic mass was found to the right of the uterus. At laparotomy this mass, which proved to be a right ovarian tumour, was removed.

Two months after excision of the tumour, she menstruated and continued to do so regularly at 30 dav intervals, while basal temperature studies showed evidence of ovulation. Her bust measurement increased by $2 \frac{1}{2}$ inches in 10 months and her figure became feminine. Although she continued to shave once a fortnight her psyche had changed and she was able to cry at a sad radio story! A month after the operation, the 17-ketosteroid excretion was $11.3 \mathrm{mg} . /$ $24 \mathrm{hrs}$., and the gonadotrophin less than 8 mouse units / 24 hrs. Two months later the corresponding figures were 19.1 and 5 respectively (Table I).

Macroscopic Appearance of the Tumour.-This was a yellow mass $(6 \times 4 \times 1 \mathrm{~cm}$.) with central cystic cavities. The surrounding solid areas were lobular and flecked with yellow.

Microscopic Description.-The tumour has no wellmarked pattern but consists of sheets of fairly large cells showing a slight tendency to aggregate into clumps, the intervening connective tissue appearing to be oedematous. Small areas of haemorrhage are also present and a few large sinuses-possibly lymphatics. The main cells of the tumour have fairly large nuclei each having a well-marked nuclear membrane and a light chromatin pattern in which frequently a nucleolus can be seen. The cytoplasm of these cells is faintly eosinophilic and.the cell margins are ill defined. In one place these cells are arranged in a radial manner giving rise to acinar structures (Fig. 5). Scattered through the tumour, singly or in groups, are cells with markedly eosinophilic cytoplasm (Fig. 6). They are usually polygonal or rounded, but occasionally elongated, and have well-defined cell boundaries. The nuclei of these cells are similar to those of the main cells of the tumour but tend to be larger each having a nucleolus, and sometimes more than one nucleolus. These cells present the following features: (1) Most, probably all, of these cells give a positive reaction with Vines stain. (2) A very few cells give a positive P.A.S. reaction. (3) The cytoplasm is finely vacuolated. Some of the larger of these cells have taken on a xanthomatous appearance. Much fat is present in the cytoplasm of these eosinophilic cells but one cannot be sure that it is confined to these cells only. (4) Many of the eosinophilic cells, possibly all, stain darkly with phosphotungstic acid haematoxylin. (5) No brown pigment or Reinke crystalloids are present (cf. Leydig cells of premature testis).

Reticulin fibres sometimes surround these groups of eosinophilic cells and at others penetrate the groups separating the individual cells. A comparison of the eosinophilic cells in these two cases with ovarian hilar cells and testicular Leydig cells is shown in Table II. It can be seen that the eosinophilic cells. of the ovarian lesions are very similar, their differences being of the same type and order as the differ- 


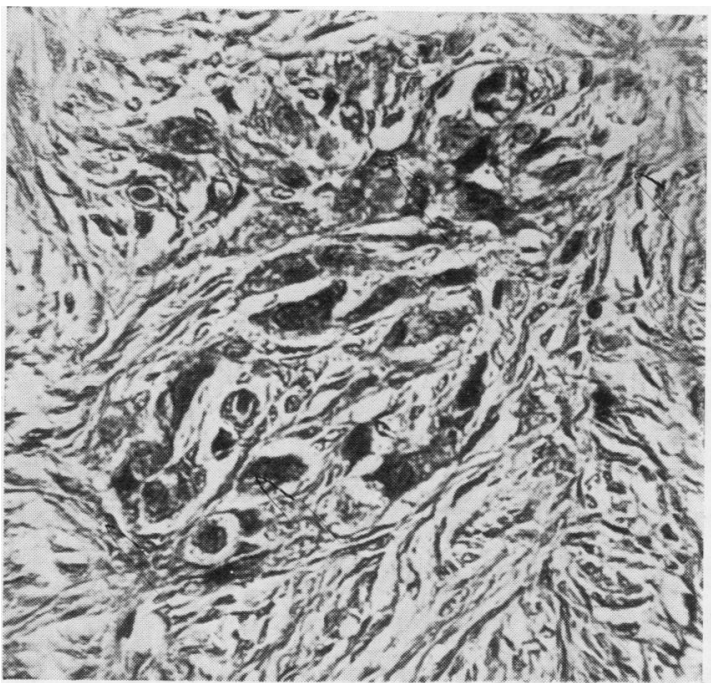

Fig. 1.-Case 1: A group of "Leydig" cells in the stroma of the ovary (Vines stain $\times 400$ ).

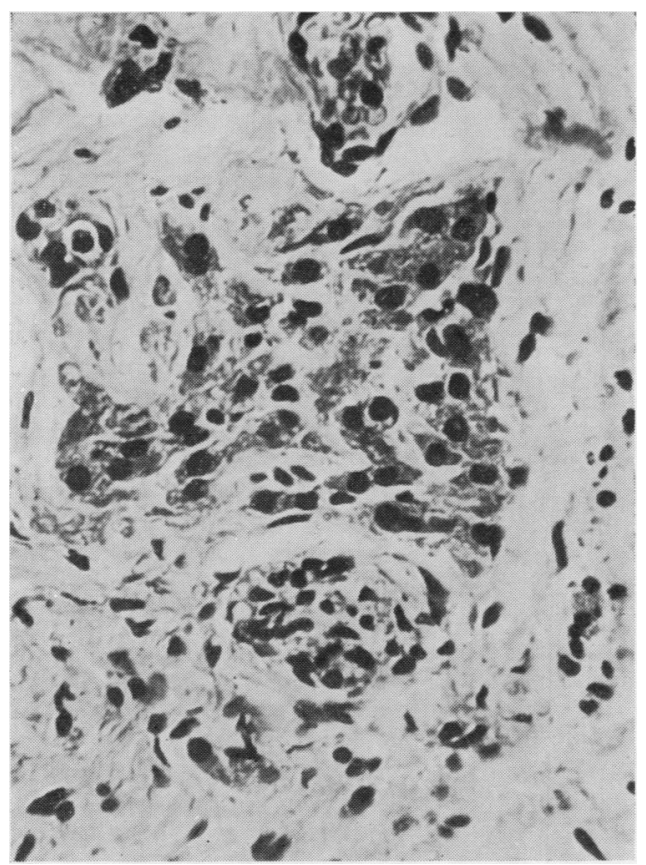

Fig. 2.-Case 1: A group of "Leydig" cells at the ovarian hilum. Note the nerve below and the blood vessel above (haematoxylin and eosin $\times 400)$.

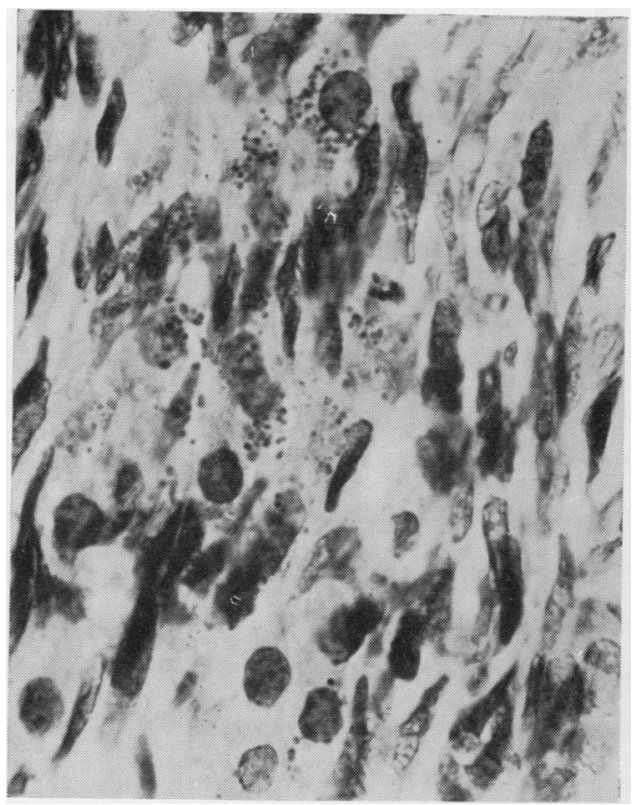

Fig. 3.-Case 1: Pigment granules in the eosinophilic cells of the ovarian stroma (haematoxylin and eosin $\times 1,000$ ).

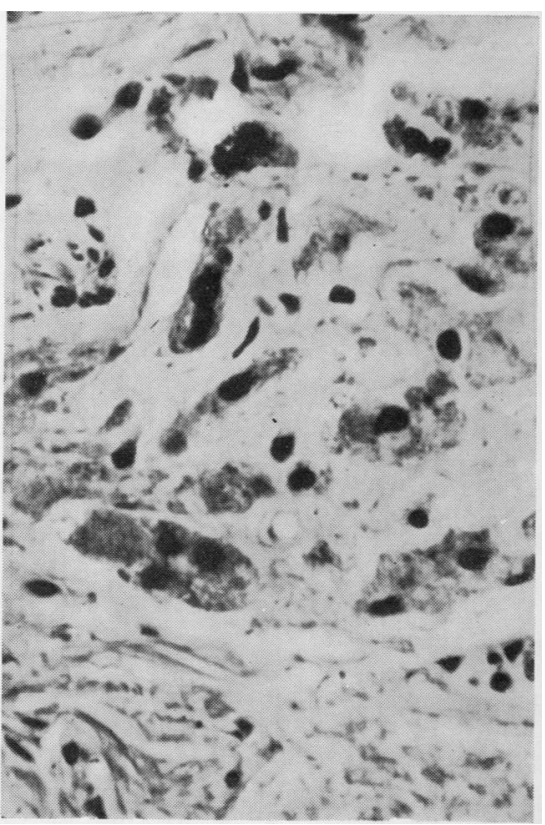

Fig. 4.-Case 1: A group of "Leydig" cells from the ovarian hilum. The cell above and to the left of the centre of the field contains a long, fairly broad, rod-shaped crystalloid of Reink: which crosses in front of the nucleus and occupies much of the cell (Masson's trichrome stain $\times 500$ ). 


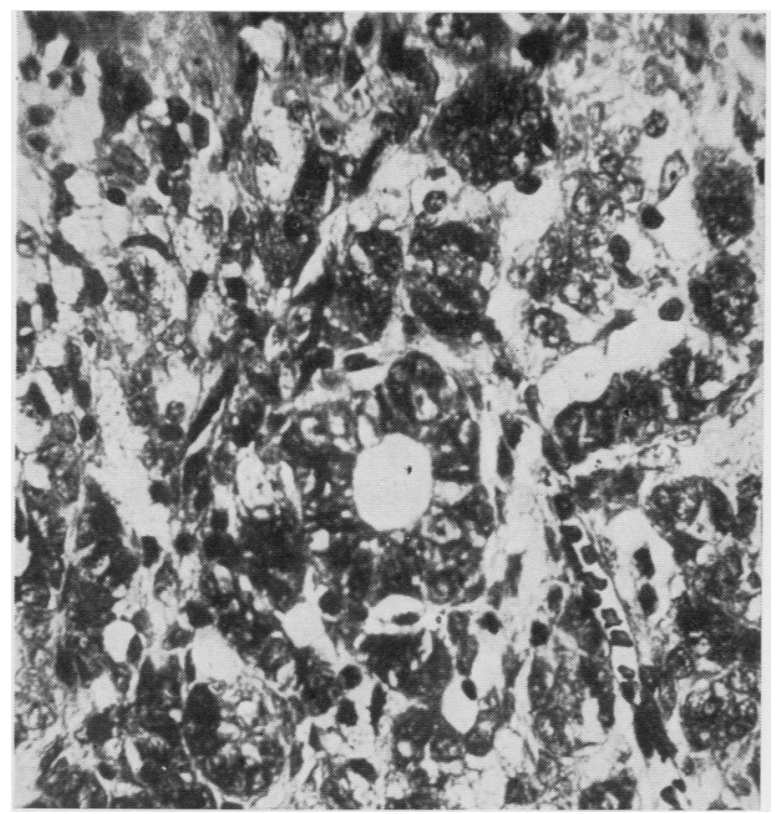

Fig. 5.-Case 2: A group of the main cells of the tumour forming an acinus (haematoxylin and eosin $\times 400$ ).

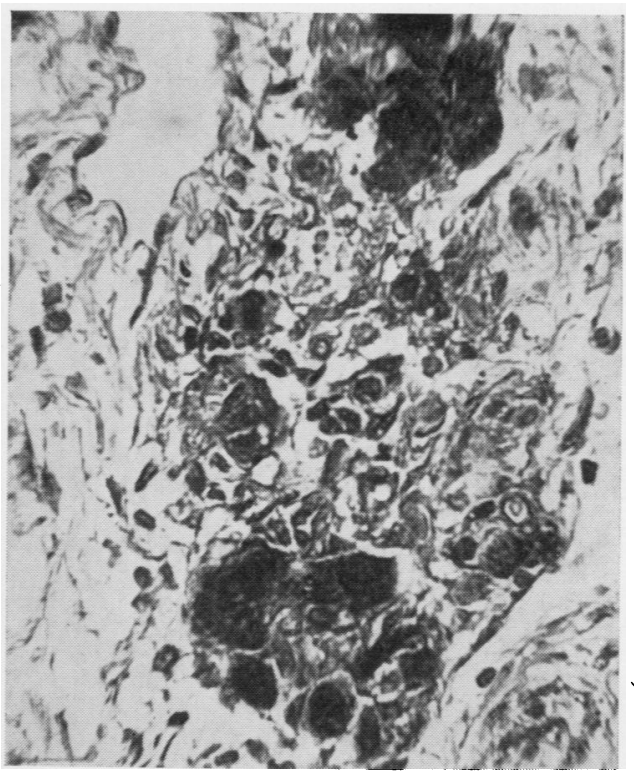

FIG. 8.-Case 3: The dark cells are eosinophilic " Leydig" cells in the band of tissue connecting the left ovary to the broad ligament. Note the close relationship of these cells to a blood vessel (Vines stain $\times$ 400),

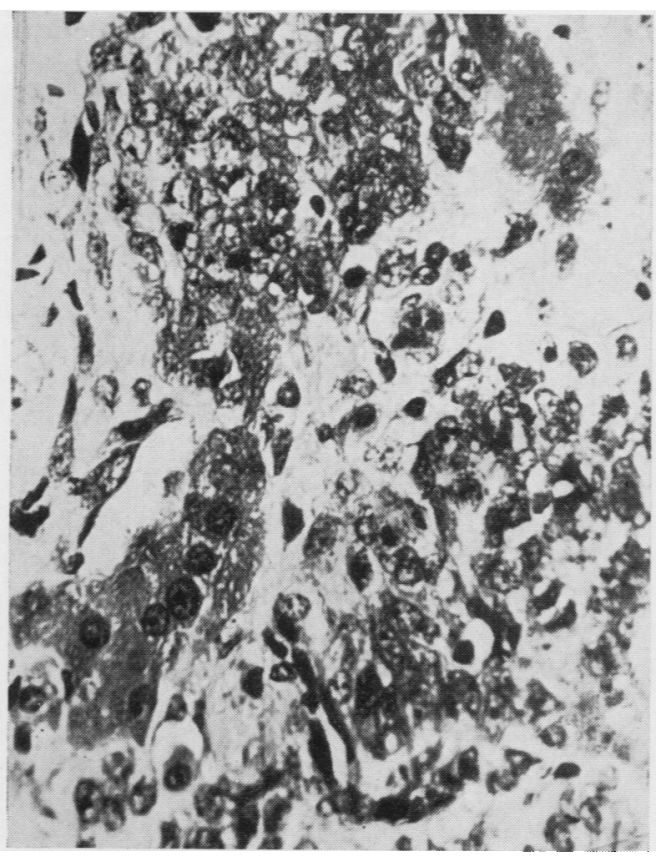

FIG. 6.-Case 2: The margins of the main cells of the tumour are ill-defined and the nuclei are irregularly arranged. The eosinophilic cells form groups having an orderly arrangement. The cytoplasm of these cells is finely vacuolated (haematoxylin and eosin $\times$ 400).

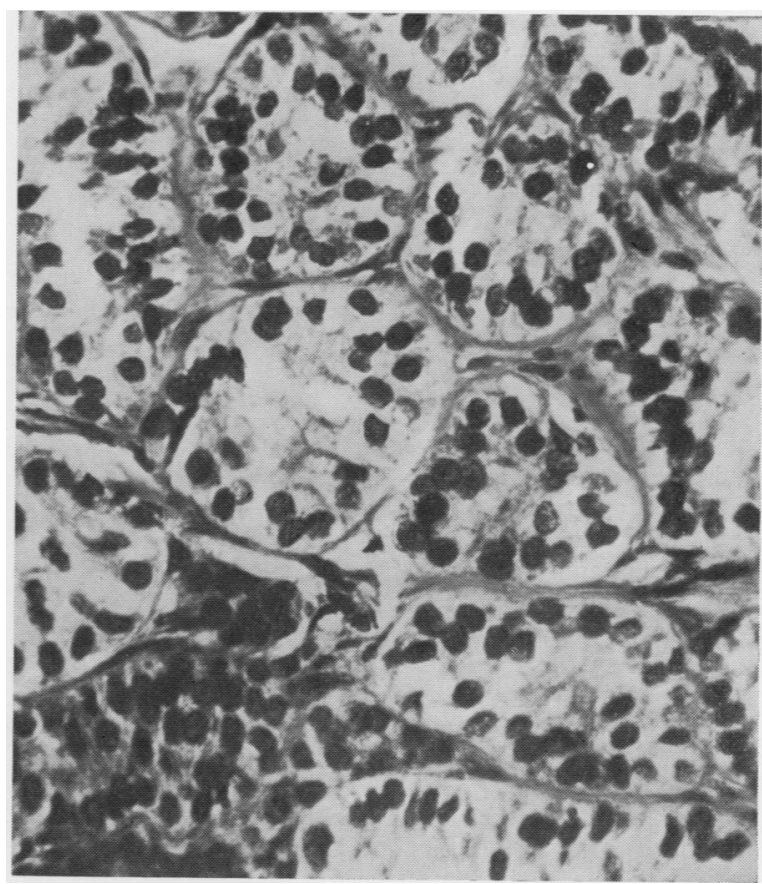

Fig. 7.-Case 3: The boundaries of the cells cannot be defined and the cytoplasmic tendrils intermingle in the lumen. There is a tendency for the acini to be lined by more than one layer of cells (haematoxylin and eosin $\times 400$ ). 
TABLE II

A COMPARISON OF THE CYTOPLASM OF "LEYDIG" CELLS

\begin{tabular}{|c|c|c|c|c|c|c|c|}
\hline & \multirow[b]{2}{*}{$\begin{array}{l}\text { Adult } \\
\text { Testis }\end{array}$} & \multirow[b]{2}{*}{$\begin{array}{l}\text { Infant } \\
\text { Testis }\end{array}$} & \multirow{2}{*}{$\begin{array}{l}\text { Ovar- } \\
\text { ian } \\
\text { Hilar } \\
\text { Cells }\end{array}$} & \multicolumn{2}{|c|}{ Case 1} & \multirow[b]{2}{*}{$\begin{array}{c}\text { Case } \\
2\end{array}$} & \multirow[b]{2}{*}{$\underset{3}{\text { Case }}$} \\
\hline & & & & $\begin{array}{c}\text { Cells } \\
\text { at } \\
\text { Hilum }\end{array}$ & $\begin{array}{c}\text { Cells } \\
\text { in } \\
\text { Stroma }\end{array}$ & & \\
\hline \multirow{7}{*}{$\begin{array}{l}\text { Pigment } \\
\text { Reinke } \\
\text { crystalloids } \\
\text { Acidophil } \\
\text { bodies .. } \\
\text { Vines reaction } \\
\text { P.A.S. } \\
\text { Vacuolation } \\
\text { Fat (Sudan IV) } \\
\text { Phosphotung- } \\
\text { stic a cid } \\
\text { haematoxylin }\end{array}$} & + & 0 & + & + & + & 0 & + \\
\hline & + & 0 & + & + & 0 & 0 & 0 \\
\hline & + & 0 & + & 0 & 0 & + & + \\
\hline & \pm & $\begin{array}{c}\text { Patchy } \\
0\end{array}$ & + & $\begin{array}{c}++ \\
+\end{array}$ & $\begin{array}{c}++ \\
+\end{array}$ & A few $^{+}$ & $\stackrel{+}{A^{\text {few }}}$ \\
\hline & + & + & + & + & + & $\begin{array}{c}\text { ent } \\
+\end{array}$ & + \\
\hline & + & + & + & + & + & + & + \\
\hline & \pm & $\begin{array}{l}\text { A few } \\
\text { cells }\end{array}$ & + & + & + & + & + \\
\hline
\end{tabular}

ences between the Leydig cells of an infant's testis and those of an adult man.

Case 3.-Mrs. G., a married woman of 62 , who had never menstruated, had for two months complained of attacks of bearing-down pain in the left groin. The last attack occurred the week before admission. On examination a mass was found in the hypogastrium extending from the pelvis and on vaginal examination this was thought to arise from the right ovary. The cervix could not be found. On opening the abdomen a large tumour, about $14 \mathrm{~cm}$. in diameter, was found on the right side. The left ovary lay at the pelvic brim together with a small cyst which had undergone torsion. No uterus was found but ribbons of muscular tissue running laterally on each side and arising from a structure resembling the broad ligament seemed to represent hypoplastic uterine horns.

The cut surface of the tumour was fawn and crossed by strands of fibrous tissue.

Microscopic Examination.-The tumour consists of small acini and tubules lined by cells with clear cytoplasm and basal nuclei. The cells lining the tubules are usually single layered but sometimes form several layers (Fig. 7). The cytoplasm trails off towards the lumen as fine tendrils which intertwine. The boundaries of the individual cells can rarely be determined, giving a syncytial appearance to the epithelium. The tubules and acini are separated by connective tissue strands, which are in places hyalinized and in others loose and oedematous. The epithelium of a number of tubules contains fine droplets of fat. In the angles between some tubules a few "interstitial" cells can sometimes be found.

The ovary on the left is composed of typical ovarian tissue and also contains a nodule having a similar structure to the right-sided tumour. In the band of tissue connecting the left ovary to the broad ligament are groups of eosinophilic cells similar to those lying between some of the tubules (Fig. 8). The nuclei of these cells are pale with dense nuclear membranes and each has a nucleolus. The cytoplasm is vacuolated and contains fat, it gives a positive Vines reaction, granules of brown pigment are present in some cells, and some cells contain P.A.S.-positive granules. The cytoplasm stains deeply with phosphotungstic acid haematoxylin. No Reinke crystals are present, but irregular masses of eosinophilic material can be seen in the cytoplasm with Masson's trichrome stain. The cells lie closely adjacent to blood vessels. Generally the cells are separated from each other by reticulin fibrils but in places fibres surround a group of cells. Thus these cells conform morphologically to hilus (or Leydig cells) both in site and cytology. A cytological comparison between these cells and the eosinophilic cells in Cases 1 and 2 is shown in the Table II.

\section{Discussion}

The "Leydig" Cells of the Ovary.-Sternberg (1949) has reviewed the present state of our knowledge of extra-testicular Leydig cells which, in women, he terms hilus cells, since they are found at the hilum of the ovary. They occur in at least $80 \%$ of ovaries. These cells are eosinophilic and form unencapsulated groups lying close to, or actually intermingling with, non-myelinated nerve trunks and also near to small blood vessels. These features are seen in extra-glandular groups of cells in Case 1 (Fig. 2). The cytoplasm of the cells is variable; it may contain fat, brown pigment granules, and Reinke crystalloids, and the mitochondria stain darkly with phosphotungstic acid haematoxylin. Reinke crystalloids are often difficult to find, but they may be associated with spheroidal hyaline acidophil bodies having the same staining reaction. The nuclei vary a little, but often contain one or more nucleoli and the cells are very occasionally multinucleated. These features are present in testicular Leydig cells and in this organ variations in numbers of cells and cytoplasmic contents also occur with age. The cells are very conspicuous in the testes of the male foetus and of premature infants, but after birth become scanty until puberty. In the infant pigment is absent but fat is present. In the adult the lipid content of the cells varies with their functional activity (Teilum, 1950). In Table II the features of the eosinophilic cells described in the tumours described here is compared with that of the testicular Leydig cells. Bearing in mind the variability of Leydig cells the morphological correspondence of the ovarian cells to the testicular ones is good except perhaps with regard to the occurrence of Reinke crystals. Others have found this feature difficult to demonstrate (Schiller, 1950).

The cells at the ovarian hila in Case 1 are morphologically identical with hilus cells and the intra-ovarian eosinophilic cells are similar to these but lack Reinke crystalloids. Brown pigment in 
the cytoplasm of intra-ovarian cells distinguishes them from lutein cells. The normal level of excretion of 17 -ketosteroids renders the origin of the "Leydig" cells from ectopic adrenal tissue unlikely.

It may be that Case 1 should more properly be termed one of hyperplasia rather than of a neoplasm. In favour of the condition being hyperplastic is its bilateral situation, but against this there is the apparent invasion of the ovarian stroma by hilus cells unless it is supposed that the intra-ovarian Leydig cells arise by metamorphosis of the stroma. In the two cases of hilus-cell hyperplasia with masculinization reported by Sternberg (1949) the cells were confined to the hilum.

Case 1 bears some resemblance to the cases of Geist and Gaines (1942) and Rottino and McGrath (1943) in which luteinization of the ovaries is described in association with masculinization. The criteria used by these workers in determining the lutein nature of the ovarian change are uncertain and hormone analyses are lacking.

The general architecture of the tumour in Case 2 is of an arrhenoblastoma of Meyer's intermediate class. The eosinophilic cells resemble the Leydig cells of the foetal testis and also the hilar cells of the infantile ovary, but lack the pigment and crystalloids of the adult cells. Berger (1942) reported a virilizing tumour of the mesovarium in a woman of 50 . This he considered to be of "Leydig" cell type although Reinke crystalloids and cytoplasmic pigment were not present. Although lutein cells have many of the features of hilar cells (including a positive Vines reaction) only a trace of pregnanediol was excreted, thus rendering it unlikely that the eosinophilic cells of this tumour were lutein. A positive Vines reaction is also given by cells in the foetal adrenal cortex, in hyperplastic adrenal cortex and in cortical adrenal tumours (Broster and Vines, 1933; Zinsser and Zinsser, 1951). Thus the eosinophilic cells of this tumour might arise from ectopic adrenal tissue near, or in, the ovary, but in adrenal hyperplasia and masculinizing adrenal tumours the excretion of 17-ketosteroids is usually greatly increased. Normal excretion can occur, although very rarely (Escamilla, 1949; Kepler and Mason, 1947; Venning and Browne, 1947). The excretion of 17ketosteroids in the two patients of Sternberg (1949) with hilar cell tumours was normal; in the patient of Waugh, Venning, and McEachern (1949) it was moderately increased but the left adrenal was also enlarged. The patient of Sachs and Spiro (1951) had a normal 17ketosteroid excretion but this may have been due to coincidental malignant cachexia. All these tumours were identifiable as "Leydig" cell tumours by their site and by the presence of Reinke crystalloids in the cytoplasm of the constituent cells. Thus in morphological features and on the grounds of hormone excretion the eosinophilic cells of Case 2 are compatible with a "Leydig" cell origin and are not lutein or adrenal in nature.

Sternberg (1949) considered that his two cases of hilus-cell tumour, and that of Berger (1942) and another mentioned in an addendum to his paper, to be the only hilus-cell tumours reported up to then. The above analysis suggests that his view is too limited and that eosinophilic cells seen in many arrhenoblastomas and described as Leydig cells (Brentnall, 1945; Teilum, 1949) without further specification of their properties are, in fact, "Leydig" (or hilus) cells. Besides arrhenoblastomas, other groups of masculinizing ovarian tumours occur associated with eosinophilic cells ; these have been termed "virilizing lipoid cell tumours" (Barzilai, 1949) and "adrenocorticoid tumours" (Herbut, 1953). It seems probable that some tumours such as that of Merivale and Forman (1951), which had a high urinary output of 17-ketosteroids, are adrenal rather than "Leydig " in type.

The Nature of the Tubular Adenomas.-The characteristic features of the epithelium lining the tubules in Case 3 are (i) the palisade arrangement of the cells, (ii) the vacuolated fibrillary cytoplasm, (iii) the ill-defined cell boundaries with interlacing cell processes (see Fig. 7), giving a syncytial appearance, and (iv) the presence of sudanophilic granules. These features are found in the Sertoli cells in atrophic testes (Innes, 1942 ; Stalker and Hendry, 1952).

Pick (1905) recognized the morphological similarity between these tumours and testicular tissue, but this similarity may also extend to their function. Pick's patient was a woman of 34 suffering from metrorrhagia and had no masculinizing signs. Likewise the patients described by Schickele (1907), Grevle (1936), Henderson (1942), and Dougal (1945) had menorrhagia or metrorrhagia. In the case recorded by Burslem, Langley, and Woodcock (1953) the patient had irregular vaginal bleeding associated with cystic hyperplasia of the endometrium. These features suggest that such tumours are oestrogenic rather than androgenic. Similar tumours occur in the testis and, although they usually have no hormonal effect (Stalker and Hendry, 1952), Teilum (1946) has described such a tumour in a man of 53 years associated with gynaecomastia and increased 
oestrogen excretion. Likewise feminizing testicular tumours of similar morphology have been described in dogs by Innes (1942) and by Huggins and Moulder (1945).

Although these tubular (or Sertoli cell) tumours of the ovary are often feminizing they are occasionally masculinizing, as in Meyer's (1930) Case 2 and in Phelan's (1934) patient. Sometimes they are hormonally indifferent and such tumours are often associated with rudimentary sex organs or their congenital absence (Novak, 1943; Jolles and Gleave, 1945 ; Goldberg and Maxwell, 1947). My Case 3 falls into this group. It is interesting to note that of the 17 cases of tubular adenoma of the testis which Stalker and Hendry (1952) have collected from the literature, 11 occurred in pseudohermaphrodites.

The Histogenesis of Sertoli Cell Tumours.Whereas "Leydig" cells appear to be a very frequent, if not constant, component of the ovary Sertoli cells are normally confined to the testis. It must however be remembered that, whatever the details of embryogenesis, Sertoli and granulosa cells have the same Anlage (Gillman, 1948) and cannot be distinguished until about the $15 \mathrm{~mm}$. stage in the human foetus (Norris, 1938). Thus it is evidently possible under abnormal conditions for the precursor of the definitive granulosa cell to mature along an alternative line and give rise to a Sertoli cell. That this can happen is shown by the case of Burslem et al. (1953) in which both a Sertoli cell tumour and a granulosa cell tumour merge. Meyer (1930) described two tumours (Cases 4 and 7) showing a similar merging.

Interference with differentiation may cause an apparent reversal of sex (Popoff, 1930 ; Berger, 1945). Dantchakoff (1936) has produced the full feminization of genetically male birds by introducing oestrone dissolved in oil into the allantoic cavity on the fourth day of incubation. After hatching these developed as intersexes. Dantchakoff (1937) has also produced masculinization of guinea-pig embryos by use of testosterone propionate. Lillie $(1916,1917)$ showed that when the foetal membranes of male and female calf embryos become united in utero so that the circulations are in continuity the female partner becomes greatly modified in the male direction forming an intersex (freemartin) with testes and male ducts. Remembering that many of these Sertoli cell tumours both in men and women are associated with congenital anomalies of the genital tract the possibility that the tumour itself is a result of disturbed gonadogenesis becomes likely, the disturbing factor possibly being in the maternal hormone system. Thus Sertoli cell tumours of this class should be considered as congenital malformations, or hamartomas, rather than blastomas. This concept may, perhaps, apply to other Sertoli cell tumours in which disturbance of development has not involved the rest of the genital tract.

\section{Conclusion}

Accepting the concept of the term arrhenoblastoma as introduced by Meyer and crystallized in the definition of Barzilai (1949) as " an ovarian tumour the cytoarchitecture of which almost exactly duplicates that seen in the different stages of male gonadogenesis," it is possible tc subdivide them into at least three groups: $(a)$ those in which "Leydig" cells are a conspicuous feature, (b) those in which "Sertoli " cells are conspicuous, and $(c)$ a mixed group in which both "Sertoli" and "Leydig" cells occur. Such a classification does not include the virilizing lipid-cell tumours, nor the masculinizing tumours with a "sarcomatous" pattern.

\section{Summary}

Two patients with masculinization of ovarian origin are described. The first had bilateral tumours, or hyperplasia, of ovarian hilus (extratesticular Leydig) cells and the second had an arrhenoblastoma in which "Leydig" cells were a conspicuous feature.

A third patient is described who had bilateral ovarian tumours of tubular, "Sertoli" cell, type associated with congenital malformation of the genital tract.

The relationship of these tumours to the classification and histogenesis of arrhenoblastomas is discussed.

I should like to thank Professor W. I. C. Morris, Dr. J. W. A. Hunter, and Dr. E. A. Gerrard for permission to publish the clinical features of their cases, and Professor A. C. P. Campbell for criticism of the manuscript. Mr. P. Stuart, A.M.I.M.L.T., also assisted me by preparing the photomicrographs.

\section{REFERENCES}

Barzilai, G. (1949). Atlas of Ovarian Tumors. Grune and Stratton New York

Berger, L. (1942). Rev. canad. Biol., 1, 539.

Brentnall C. Canad. med. Ass. J., 52, 445. Brit. Emp., 52, 235.

Broster, L. R., and Vines, H. W. C. (1933). The Adrenal Cortex. Lewis, London.

Burslem, R. W., Langley, F. A., and Woodcock, A. S. (1953). In the press.

Dantchakoff, V. (1936). Bull. biol., 70, 241

(1937). Ibid., 71, 269.

Dougal, D. (1945), J. Obstet. Gynaec. Brit. Emp., 52, 370.

Escamilla R. F. (1949). Ann. intern. Med., 30, 249.

Geist, S. H., and Gaines, J. A. (1942). Amer. J. Obstet. Gynec., 43, 975 .

G75. (1948). Contr. Embryol. Carneg. Instn (No. 210), $32,83$.

Gillman, J. (1948). Contr. Embryol. Carneg. Instn (No. 210), 32, 83

Goldberg, M. B., and Maxwell, A. F. (1947). J. clin.

Henderson, D. N.: 1942). Amer. J. Obstet. Gynec., 43, 194. 
Herbut, P. A. (1953). Gynecological and Obstetrical Pathology. Kimpton, London.

Huggins, C., and Moulder, P. V. (1945). Cancer Res., 5, 510.

Innes, J. R. M. (1942). J. Path. Bact., 54, 485.

Javert, C. T., and Finn, W. F. (1951).' Cancer, 4, 60

Jolles, B., and Gleave, H. H. (1945). J. Path. Bact., 57, 435.

Kepler, E. J., and Mason, H. L. (1947). J. clin. Endocr., 7, 543.

Lillie, F. R.' (1916). Science, 43, 611 .

Lillie, F. R. (1916). Science, 43, 61.

Merivale, W. H. H., and Forman, L. (1951). Brit. med. J. 1, 560 .

Meyer, R. (1915). Z. Geburtsh. Gynäk., 77, 243, 505.

- (1930). Beitr. path. Anat., 84, 485.

(1931). Amer. J. Obstet. Gynec., 22, 697.

Norris, E. H. (1938). Amer. J. Cancer, 32, 1.

Novak, E. (1952). Gynecologic and Obstetric Pathology, 3rd ed. Saunders, Philadelphia.

Novak, J. (1943). Amer. J. Obstet. Gynec., 45, 856.
Phelan, G. W. (1934). Ibid., 27, 748.

Pick, L. (1905). Arch. Gynäk., 76, 191.

Popoff, N. W. (1930). Arch. Path., Chicago, 9, 31.

Rottino, A., and McGrath, J. F. (1943). Amer. J. Obstet. Gynec., 45 863 .

Sachs, B. A., and Spiro, D. (1951). J. clin. Endocr., 11, 878.

Schickele G. (1907). Beitr. Geburtsh. Gynäk., 11, 263.

Schiller, W. (1950). Progress in Gynecology, vol. 2, p. 1, ed. Meigs, J. V., and Sturgis, S. H. Heinemann, London.

Stalker, A. L., and Hendry, W. T. (1952). J. Path. Bact., 64, 161.

Sternberg, W. H. (1949). Amer. J. Path., 25, 493.

Teilum, G. (1946). Acta path. microbiol. scand., 23, 252. - (1949). J. clin. Endocr., 9, 301.

Venning E. Acta endocr., Kbh., 4, 43.1947) J. clin. Endocr., 7, 79.

Waugh, D., Venning, E. H., and McEachern, D. (1949). Ibid., 9, 486.

Zinsser, A. D., and Zinsser, H. H. (1951). Arch. Path., Chicago, 51, 393. 